\title{
Geochemical research of asphaltite formation in the Orenburg region
}

\author{
Maria Zakharchenko, ${ }^{1,}$, Irina Salihova ${ }^{1}$, and Vagif Kerimov $^{1}$ \\ ${ }^{1}$ Russian State Geological Prospecting University, Department of geology and exploration of \\ hydrocarbon deposits, 23 Miklouho-Maclay, Moscow, Russia
}

\begin{abstract}
The results of the studies of the physicochemical properties and genesis of asphaltites from the deposits of the Orenburg region are considered. Based on the data of a study on the distribution of hydrocarbon biomarkers ( $n$-alkanes, isoprenanes, steranes, and terpanes), it was found that deposit formation occurred in carbonate layers under reducing conditions. The distribution of steranes and terpanes confirmed a sufficient maturity of the asphaltite. The $\mathrm{C} 28 / \mathrm{C} 29$ sterane ratio of 0.31 corresponds to Silurian age according to Grantham or to Silurian-Devonian age according to the pregnane coefficient (a ratio of the sum of $\mathrm{C} 21-\mathrm{C} 22$ pregnanes to the sum of $\mathrm{C} 21-\mathrm{C} 22$ pregnanes and $\mathrm{C} 27-\mathrm{C} 29$ regular steranes) of $9.0 \%$. Thus, it is likely that asphaltites from the Ivanovk deposit in the Orenburg region were redeposited in Silurian/Devonian source rock formations.
\end{abstract}

At present, the production of oil and bituminous polymeric materials from solid natural bitumens is of great interest. The greatest bitumen reserves in the world are located in Canada. About 700 deposits of bituminous rocks were revealed in the territory of the former Soviet Union, predominantly in Russia, Kazakhstan, and Azerbaijan. In Russia, the natural bitumen resources are from 30 to 75 billion tons according to different estimations. At the same time, natural bitumens as an important and significant portion of the rawmaterial base of hydrocarbons in Russia is almost not taken into account and not involved in the national economic development.

The Volga-Ural oil- and gas-bearing province possesses the greatest in Russia known and proven reserves of bitumens, which are in essence asphaltites in the Orenburg oblast. Among them, Ivanovka, Kazanka, Sadkinskii, and other asphaltite deposits are known (Fig. 1). Asphaltites are one of the groups of solid natural bitumens - the derivatives of oil formed as a result of its changes on the earth's surface or at small depths. The term was introduced by American researcher Blake in 1890. They occur in the form of asphaltite veins and stratified deposits. Elemental composition (wt \%): C, 76-86; H, 8-12; S, 0.25-9; $\mathrm{N}, 0.3-1.8$; and $\mathrm{O}, 2-9$. A high asphaltene content (to 70\%) and a relatively low oil content (to $30 \%$ ) are typical. Among the asphaltites, gilsonites (density, $1050-1150 \mathrm{~kg} / \mathrm{m} 3 ; \mathrm{Tm}=$ $100-200^{\circ} \mathrm{C}$ ) and higher molecular weight grahamites (density, $1150-1200 \mathrm{~kg} / \mathrm{m} 3$; melts with decomposition at $T=200-300^{\circ} \mathrm{C}$ ). Interest in studying the composition and properties and developing the processing of asphaltites as a form of solid fossil fuels has quickened in

\footnotetext{
*Corresponding author: r.mustaev@ mail.ru
} 
the past few years. This is primarily due to their huge geological reserves and special features of the elemental, group, and fractional composition [1-4]. The majority of asphaltites are characterized by a high and, in a number of cases, unique concentration of heteroatoms and heteroatomic components, including metals; they are complex organomineral raw materials.

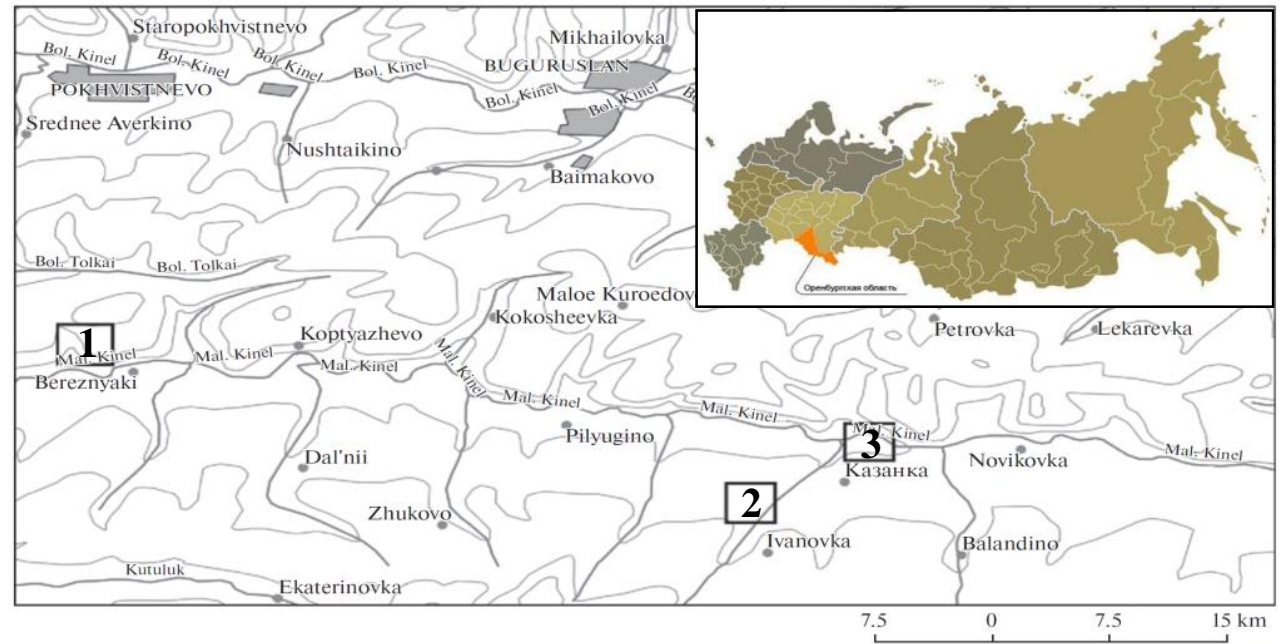

Fig. 1. Survey map of the arrangement of asphaltite deposits (Buguruslan region, Orenburg oblast): (1) Sadkinskii block, (2) Ivanovka block, and (3) Kazanka block.

A study of the geochemical conditions of asphaltite formation [5-10], in particular, their correlation with the deposits of oil, and also the development of processes for the transformation of oil into asphaltites are problems of considerable current importance.

Asphaltites of the Ivanovka and Kazanka deposits occur at a depth of 400 m, and halite (rock salt) is the enclosing rock. The average thickness of the lens deposit is $4-5 \mathrm{~m}$. Asphaltite from the Ivanovka deposit is $99.9 \%$ pure unique hydrocarbon polymer. The asphaltite reserves of the Ivanovka deposit were estimated at about 10 million tons. The resources of the Kazanka asphaltite occurrence were evaluated at 6 million tons. With consideration for the geological structure of the territory of this region and the position of the lens deposit of asphaltite, a direct relationship between the sections and the continuous occurrence of the mineral is obvious. The Ivanovka layer and the Kazanka occurrence are a single deposit. The promising extractable resources of the united section were evaluated at about 20 million tons of asphaltite. The dimensions of the deposit are about $3000 \mathrm{~m}$ in length and $5000 \mathrm{~m}$ in width. Furthermore, the asphaltite lens of the Ivanovka deposit is not contoured from the north and the south.

The analysis of the distribution of $n$-alkanes and isoprenanes in the oil fraction of asphaltite from the Ivanovka deposit was carried out by capillary gas-liquid chromatography (GLC) on a Bruker 430-GC instrument with a flame-ionization detector with a temperature program from 80 to $320^{\circ} \mathrm{C}$ at a heating rate of $4 \mathrm{~K} / \mathrm{min}$. Hydrogen was the carrier gas. The hydrocarbons were separated on an HP-1 capillary column $(25 \mathrm{~m} \times 0.25$ $\mathrm{mm})$. The distribution of steranes and terpanes was investigated by gas chromatographymass spectrometry (GC-MS) on an HP-6890N/5975C instrument with the use of a computer data processing system in the SIM mode with the detection of ions with $\mathrm{m} / \mathrm{z} 217$, 218, 191, and 177 for tri-, tetra-, and pentacyclic terpanes.

Fig. 2 represent data on the distribution of $n$-alkanes and isoprenanes in the Ivanovka asphaltite deposit, and Fig. 3 shows a chromatogram of the oil fraction of asphaltite. From 
Fig. 2, it is evident that the distribution of $n$-alkanes from C9 to C33 is unimodal with a maximum at $\mathrm{C} 14$.

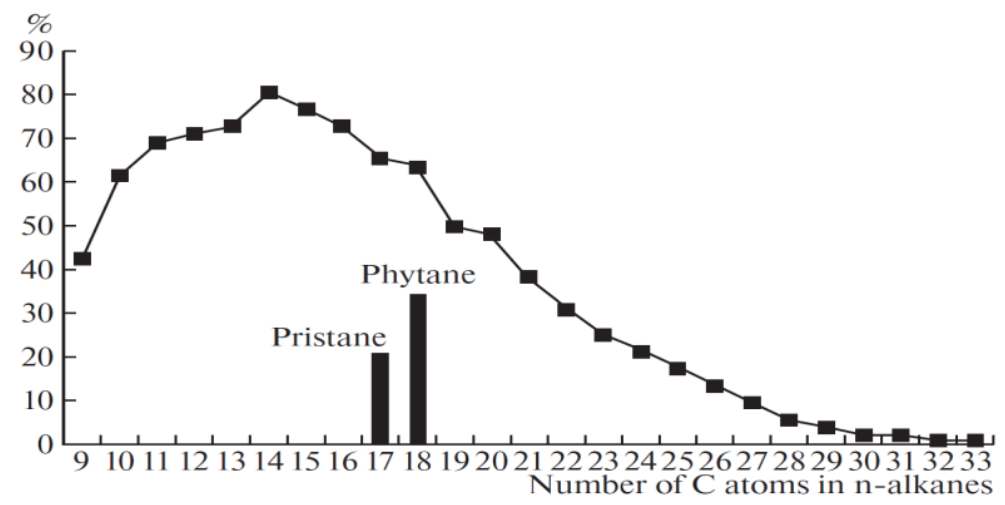

Fig. 2. Distribution of $n$-alkanes and isoprenanes in asphaltite from the Ivanovka deposit (according to the GLC data).

Table 1 summarizes the geochemical characteristics of Ivanovka asphaltite in terms of $n$-alkanes and isoprenanes. Based on the value of a pristane/phytane genetic index, it is possible to conclude that the asphaltite corresponds to a fluid of marine origin. This is also evident from other indices: pristane $/ n-\mathrm{C} 17 \mathrm{H} 36$ and phytane $/ n-\mathrm{C} 18 \mathrm{H} 38$. Note that the chromatogram exhibited a sufficiently large naphthene-aromatic maximum: the (pristane + phytane)/ $\mathrm{Nb}$ and $(n-\mathrm{C} 17 \mathrm{H} 36+n-\mathrm{C} 18 \mathrm{H} 38) / \mathrm{Nb}$ ratios were 0.94 and 2.06, respectively (Fig. 3 ).

Table 1. Geochemical characteristics of asphaltite from the Ivanovka deposit in terms of n-alkanes and isoprenanes.

\begin{tabular}{|c|c|}
\hline Ratio & Value \\
\hline Pristane/phytane & 0.58 \\
\hline Pristane $/ n-\mathrm{C} 17 \mathrm{H} 36$ & 0.32 \\
\hline Phytane $/ n$-C18H38 & 0.59 \\
\hline (Pristane + phytane $) / \mathrm{Nb}^{*}$ & 0.94 \\
\hline$(n-\mathrm{C} 17 \mathrm{H} 36+n$-C18H38)/Nb & 2.06 \\
\hline$\sum(n-\mathrm{C} 13-n-\mathrm{C} 15) / \sum(n-\mathrm{C} 23-n-\mathrm{C} 25)$ & 3.44 \\
\hline $\mathrm{KC} * *$ & 0.97 \\
\hline
\end{tabular}

$* \mathrm{Nb}$ is the naphthene background.

$* * K \mathrm{C}=(n-\mathrm{C} 15 \mathrm{H} 32+n-\mathrm{C} 17 \mathrm{H} 36) / 2 \cdot n-\mathrm{C} 16 \mathrm{H} 34$ is the carbon preference index.

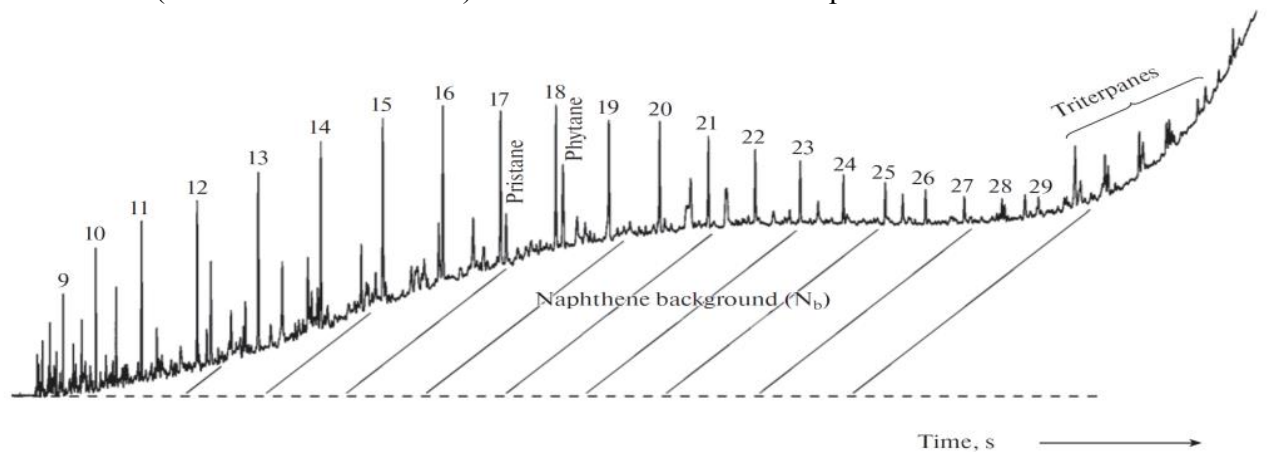

Fig. 3. Chromatogram of asphaltite from the Ivanovka deposit, P2gd. The conditions of analysis are specified in the text. (Numbers above peaks indicate the numbers of carbon atoms in $n$-alkanes). 
As a result of the experimental investigations, the distribution of steranes was obtained (Fig. 4). According to the coefficients of maturity $\mathrm{K}_{\mathrm{m}}^{1}$ and $\mathrm{K}_{\mathrm{m}}{ }_{\mathrm{m}}(0.53$ and 0.79 , respectively), which almost reached equilibrium values, it was concluded that the asphaltite is sufficiently mature. The diasteranes/regular steranes ratio of 0.04 indicates that deposit formation occurred in carbonate rock masses.

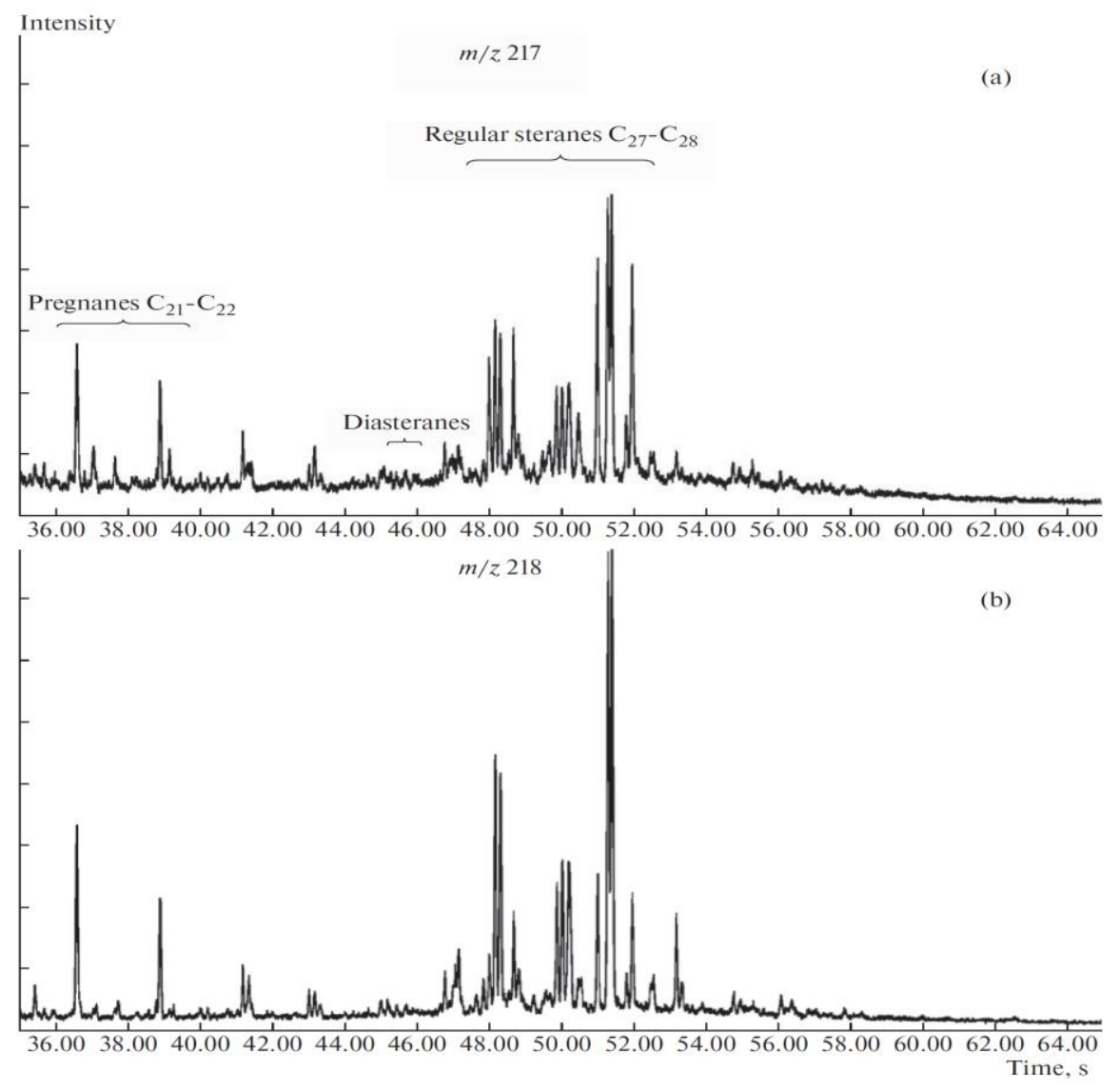

Fig. 4. Mass chromatograms of the steranes of asphaltite from the Ivanovka deposit, P2gd.

Because the asphaltite was formed under sea conditions, the age of source rocks, which generated asphaltite, can be judged from the Grantham coefficient [11] and the pregnane index $[12,13]$ (Fig. 5). Thus, the C28/C29 sterane ratio of 0.31 corresponds to the Silurian according to Grantham, whereas the age is older than the Silurian according to the pregnane coefficient - a ratio of the sum of pregnanes C21-C22 to the sum of pregnanes $\mathrm{C} 21-\mathrm{C} 22$ and regular steranes $\mathrm{C} 27-\mathrm{C} 29$, which is $9.0 \%$. However, for the organic matter of rocks of the Permian age, in which asphaltite is deposited, these coefficients should be 0.58 and $25 \%$, respectively. In other words, asphaltite occurs in a redeposited formation.

Among terpanes, an increased concentration of C35 homohopane (the ratio H35/H34 = 1.40) was observed, and adiantane prevailed over hopane $(\mathrm{H} 29 / \mathrm{H} 30=1.31)$.

This fact indicates that the deposition accumulation occurred in carbonate strata under reducing conditions. The high H30/St29 ratio is indicative of the wide development of bacterial processes in the sediments. Note that neoadiantane and homohopane were absent from the test samples. Furthermore, a relatively low concentration of 22,29,30-18 $\alpha(\mathrm{H})$ trisnormethylhopane Ts (the Ts/Tm ratio was 0.12 ) should be noted. 


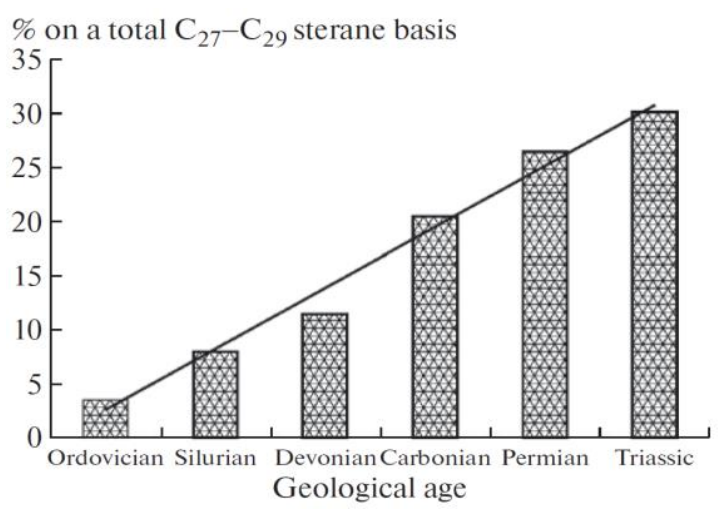

Fig. 5. C21-C22 pregnane index as a function of geological time (based on the example of oils from the Timan-Pechora province) [12].

Thus, the distribution of the hydrocarbon biomarkers ( $n$-alkanes, isoprenanes, steranes, and terpanes) indicates that the deposition of sediments occurred in the carbonate strata under reducing conditions. The distribution of steranes and terpanes makes it possible to draw the conclusion that the asphaltite is sufficiently mature, and it occurs in a redeposited formation; it is most likely that Silurian/Ordovician rocks are the source bed. For the final confirmation of the above conclusions, it is necessary to study the distribution of hydrocarbon biomarkers in the organic matter of the Permian system and the products of the mild thermolysis of asphaltenes with the subsequent study of the distribution of hydrocarbon biomarkers for a comparison with them in the asphaltite.

This study was supported by the Ministry of Education and Science of the Russian Federation (state contract no. 10.6569.2017/BCh).

\section{References}

1. K.E. Peters, AAPG Bulletin, 70, 3, 318, (1986)

2. A.L. Lapidus, V.Y. Kerimov, R.N. Mustaev, E.M. Movsumzade, M.V. Zakharchenko, Oil Shale, 35(2), 113, (2018)

3. I.S. Guliev, V.Yu. Kerimov and R.N. Mustaev, Doklady Earth Sci., 471, 1, 1109, (2016)

4. V.Yu. Kerimov, A.V. Osipov, E.A. Lavrenova, Neftyanoe khozyaystvo - Oil Industry, 4, 33 (2014)

5. V.Yu. Kerimov, R.N. Mustaev, S.S. Dmitrievsky, V.A. Zaitsev, Neftyanoe khozyaystvo - Oil Industry, 9, 18 (2016)

6. V.Y. Kerimov, M.Z. Rachinsky, R.N. Mustaev, A.V. Osipov, Doklady Earth Sciences, 476, 1, 1066 (2017)

7. V.Yu. Kerimov, R.N. Mustaev, N.Sh.Yandarbiev, E.M. Movsumzade Oriental J.Chem. 33, 2, 879 (2017)

8. R.N. Mustaev, W.N. Hai, V.Y. Kerimov, E.A. Leonova, Geomodel 2015 - 17th Scientific-Practical Conference on Oil and Gas Geological Exploration and Development (2015)

9. I.S. Guliyev, V.Y. Kerimov, A.V. Osipov, R.N. Mustaev, SOCAR Proceedings, 1, 4, (2017)

10. M.Z. Rachinsky, V.Y. Kerimov, Scrivener Publishing Wiley, 640, (2015) 
11. P.J. Grantham and L.L. Wakefield, Org. Geochem., 12, 61, (1988)

12. I.A. Matveeva and G.N. Gordadze, Geokhimiya, 4, 455, (2001)

13. G.N., Gordadze, Moscow: RGU Nefti i Gaza im. I.M. Gubkina, (2015) 